\title{
Tribal Women Experiencing Panchayati Raj Institution in India with Special Reference to Arunachal Pradesh
}

\author{
Dr. Ajay Kumar Yadav \\ Department of Political Science, Rajiv Gandhi University, Rono Hills, Itanagar
}

\begin{abstract}
The role of women in any tribal communities is crucial. A tribal woman occupies an important place in the socio-economic structure of the society. They exercise free and firm hand in all aspects related to their social and economic life. In Agriculture, tribal women play a crucial role in wide range of activities and contributing to sustainable development. Tribal communities are at slow stages of political development. The role of tribal women in politics has been underrepresented. But with the introduction of the $73^{\text {rd }}$ Constitutional Amendment Act and the reservation of one-third of its seats for STs, SCs and Women in Grass-roots politics, the participation of tribal women in panchayat politics has been noticed among the tribal communities. Panchayati Raj Institution can be assumed as a mechanism for rapid development of the tribal communities and also for greater participation and empowerment of tribal women. In Arunachal Pradesh, the Panchayat system was introduced as far the- North East Panchayati Raj Regulation, 1967. Elections to Panchayats were held seven (7) times between 1968 and 1992, but the result showed that at the Anchal Samiti level in 1987, there was only one (1) and in 1992 there were only three (3) female elected representatives. In higher decision making bodies also i.e., Legislative Assembly the women had never exceed 5 (five) per cent in the state. Hence, an attempt has been carried out in this paper to study the participation of tribal women in panchayat categorically on the basis of election held in April 2003, May 2008 and May 2013 respectively.
\end{abstract}

Key words: Panchayati Raj Institution, Elected Women Representatives, Empowerment, Tribal Women, Participation.

\section{INTRODUCTION}

The tribal population of the country is $10,42,81,034$, constituting $8.6 \%$ of the total population $(1.21$ billion) as per 2011 census. Of total 10.43 crore tribal populations 5, 24, 09,823 are males and 5, 18, 71,211 are females. $89.97 \%$ of them live in rural areas and $10.03 \%$ in urban areas. Most of the tribal population in India are found in two distinct geographical areas - the Central India and the North- Eastern Area. More than half of the Scheduled Tribe population is concentrated in Central India, i.e., Madhya Pradesh, Chhattisgarh, Jharkhand, Andhra Pradesh, Maharashtra, Orissa, Gujarat and Rajasthan. The other distinct area is the North East i.e., Assam, Nagaland, Mizoram, Manipur, Meghalaya, Tripura, Sikkim and Arunachal Pradesh. Tribal communities live in various ecological and geo-climatic conditions ranging from plains and forests to hills and inaccessible areas. In tribal communities, the role of women is substantial and crucial. A tribal woman occupies an important place in the socio-economic structure of the society. They exercise free and firm hand in all aspects related to their social and economic life. In Agriculture, tribal women play a crucial role in wide range of activities and contributing to sustainable development. Tribal communities are at slow stages of political development. The role of tribal women in politics has been underrepresented. But with the introduction of the $73^{\text {rd }}$ constitutional amendment Act and the reservation of one-third of its seats for STs, SCs and Women in Grass-roots politics, the participation of tribal women in panchayat has been noticed among the tribal communities. Among the Northeast state, first to enforce the provision of $73^{\text {rd }}$ constitutional Amendment Act are Sikkim in the year 1993, Assam, Manipur and Tripura in 1994 and lastly in 1997 Arunachal Pradesh has implemented the Panchayati Raj Institution under the guidelines of $73^{\text {rd }}$ constitutional Amendment Act. In view of the diverse patterns of Panchayat Institutions in North-East region; the $73^{\text {rd }}$ Constitution Amendment Act, 1992 has provided a special constitutional arrangement under Article 244 that the Act shall not be applicable upon the states of Nagaland, Meghalaya, and Mizoram and hills area of Manipur. Panchayati Raj Institution can be assumed as a mechanism for rapid development of the tribal communities and also for greater participation and empowerment of tribal women.

\section{THE PROBLEM}

In Arunachal Pradesh, the Panchayat system was introduced as far the- North East Panchayati Raj Regulation, 1967. Elections to Panchayats were held seven (7) times between 1968 and 1992, but the result showed that at the Anchal Samiti level in 1987, there was only one (1) and in 1992 there were only three (3) 
female elected representatives. In higher decision making bodies also i.e., Legislative Assembly the women had never exceed 5 (five) per cent in the state. Since the role of Panchayati Raj Institution in empowerment of women has attained paramount importance; it is natural to have in depth study as to whether the objectives of implementation of 33 per cent reservation of seats for women in third tier of the democracy have achieved the goals of women empowerment especially in the case of Arunachal Pradesh where women's position in the society has not been wholly subordinate to male counterparts unlike in other parts of the country.

\section{OBJECTIVES OF THE STUDY}

1. To understand the percentage of tribal women in Panchayati Raj Institution

2. To understand whether tribal women are fulfilling the existing quota of one-third reservation of seats

3. To compare the tribal women participation in three phase of Panchayat election

\section{METHODOLOGY OF THE STUDY}

Descriptive research design has been adopted to study the tribal women's of Arunachal Pradesh. The purpose of this research design is to describe the percentage of tribal women participation in Panchayati Raj Institution and also to understand that whether reservation has made some significant change so as to provide them political empowerment which encompasses social and economic empowerment. The data for the present study have been gleaned from both primary and secondary sources which have been duly acknowledged.

\section{PARTICIPATION OF TRIBAL WOMEN IN PANCHAYATI RAJ INSTITUTION}

As it has been already stated that the participation of women in Panchayat in Arunachal Pradesh has not been so much encourage before the introduction of $73^{\text {rd }}$ constitutional amendment Act, 1992. The $73^{\text {rd }}$ constitutional amendment Act heralds a new opportunity to the millions of women to test their experiences in panchayat politics in India, by reserving one-third of its seats especially for the women besides for STs and SCs. To meet the requirement of the $73^{\text {rd }}$ Constitutional Amendment Act, the Arunachal Government issued an ordinance (The Arunachal Pradesh Panchayati Raj Ordinance 1994), which later on was renamed as Arunachal Pradesh Panchayat Raj Act 1997. The Act has come into effect from $14^{\text {th }}$ November 2001. It also heralds a new opportunity for the tribal women of Arunachal Pradesh to enter into the grassroots politics by providing one third reservations of seats in the Panchayats. As per the Act, state has already hold three consecutive Panchayat elections viz, 2003, 2008 and 2013 respectively. And in the state (Arunachal Pradesh), women are making significant gains by taking active participation in various activities of the Panchayati Raj Institution. The further detailed description of the Panchayat election held in 2003, 2008 and 2013 in the state has been carried out with the help of the data imparted in table-1, table- 2 and table- 3 respectively.

Table-1 shows that of total 8,260 elected seats, women representatives hold 3,183 seats which comprise 38.54 per cent of the total elected seats. Moreover, comparative analysis among the districts shows that West Kameng district has hold highest numbers of women representatives which comprise 44.43 per cent of total 601 elected seats and West Siang district hold lowest numbers of women representatives which comprise 34.75 per cent of total 1025 elected seats of the district.

Table-2 shows that of total 9,287 elected seats, women representatives hold 3,889 seats which comprise 41.88 per cent of the total elected seats. Moreover, comparative analysis among the districts shows that East Kameng district has hold highest numbers of women representatives which comprise 50.50 per cent of total 602 elected seats and Upper Siang district hold lowest numbers of women representatives which comprise 32.28 per cent of total 285 elected seats of the district.

Table-3 shows that of total 9,231 elected seats, women representatives hold 4,069 seats which comprise 44.08 per cent of the total elected seats. Moreover, comparative analysis among the districts shows that West Kameng district has hold highest numbers of women representatives which comprise 52.20 per cent of total 590 elected seats, followed by East Kameng (52\%) of 600 elected seats of the district. Tirap district has hold lowest numbers of women representatives which comprise 31.90 per cent of total 395 elected seats of the district.

\section{VI. $\quad$ FINDINGS OF THE STUDY}

The following are the findings of the study-

- The study noticed an increasing rate of tribal women participation in Panchayati Raj Institution. In 2003 panchayat election women representatives hold 38.54 per cent of the total seats while in 2013 panchayat election women representatives hold 44.08 per cent of the total seats in the state.

- A large numbers of women representatives have also notices that contested from open seats and thus defeated their male counterparts by holding 50 per cent of seats in the district (West Kameng, East Kameng, etc.).

- It is also noticed that in few of the district (Tirap, Upper Siang, etc.) women representatives has not performed well and even unable to hold 33 per cent of the total seats. 
Table-1

\begin{tabular}{|c|c|c|c|c|c|c|c|c|c|c|c|c|c|}
\hline \multirow{3}{*}{$\begin{array}{l}\text { S1. } \\
\text { No. }\end{array}$} & \multirow{3}{*}{$\begin{array}{l}\text { Name of } \\
\text { District }\end{array}$} & \multicolumn{9}{|c|}{ Elected No of Male / Female } & \multirow{2}{*}{\multicolumn{3}{|c|}{ GRAND TOTAL }} \\
\hline & & \multicolumn{3}{|c|}{ GPM } & \multicolumn{3}{|c|}{ ASM } & \multicolumn{3}{|c|}{ ZPM } & & & \\
\hline & & $\mathrm{T}$ & $\mathrm{M}$ & $\bar{F}$ & $T$ & $\mathrm{M}$ & $\bar{F}$ & $\mathrm{~T}$ & $\mathrm{M}$ & $\mathrm{F}$ & $T$ & $\begin{array}{c}\mathrm{M} \\
(\%)\end{array}$ & $\begin{array}{c}F \\
(\%)\end{array}$ \\
\hline 1. & Tawang & 293 & 170 & 123 & 80 & 51 & 29 & 6 & 4 & 2 & 379 & $\begin{array}{c}225 \\
(5937)\end{array}$ & $\begin{array}{c}154 \\
(40.63)\end{array}$ \\
\hline 2. & $\begin{array}{c}\text { East } \\
\text { Kameng }\end{array}$ & 400 & 225 & 175 & 118 & 75 & 43 & 10 & 7 & 3 & 528 & $\begin{array}{c}307 \\
(58.14)\end{array}$ & $\begin{array}{c}221 \\
(41.86)\end{array}$ \\
\hline 3. & $\begin{array}{c}\text { West } \\
\text { Kameng }\end{array}$ & 496 & 269 & 227 & 96 & 59 & 37 & 9 & 6 & 3 & 601 & $\begin{array}{c}334 \\
(55.57)\end{array}$ & $\begin{array}{c}267 \\
(44.43)\end{array}$ \\
\hline 4. & Papumpare & 337 & 208 & 129 & 77 & 50 & 27 & 10 & 7 & 3 & 424 & $\begin{array}{c}265 \\
(6250)\end{array}$ & $\begin{array}{c}159 \\
(3750)\end{array}$ \\
\hline 5. & $\begin{array}{c}\text { Lower } \\
\text { Subansiri }\end{array}$ & 621 & 328 & 293 & 190 & 123 & 67 & 14 & 10 & 4 & 825 & $\begin{array}{c}461 \\
(55.88)\end{array}$ & $\begin{array}{c}364 \\
(44.12)\end{array}$ \\
\hline 6. & $\begin{array}{l}\text { Kurung } \\
\text { Kumey }\end{array}$ & 571 & 347 & 224 & 161 & 106 & 55 & 13 & 8 & 5 & 745 & $\begin{array}{c}461 \\
(61.88)\end{array}$ & $\begin{array}{c}284 \\
(38.12)\end{array}$ \\
\hline 7. & $\begin{array}{c}\text { Upper } \\
\text { Subansiri }\end{array}$ & 497 & 290 & 207 & 145 & 95 & 50 & 13 & 9 & 4 & 655 & $\begin{array}{c}394 \\
(60.15)\end{array}$ & $\begin{array}{c}261 \\
(39.85)\end{array}$ \\
\hline 8. & East Siang & 561 & 354 & 207 & 144 & 95 & 49 & 11 & 7 & 4 & 716 & $\begin{array}{c}456 \\
(63.69)\end{array}$ & $\begin{array}{c}260 \\
(3631)\end{array}$ \\
\hline 9. & $\begin{array}{l}\text { West } \\
\text { Siang }\end{array}$ & 827 & 536 & 291 & 211 & 141 & 70 & 18 & 12 & 6 & 1056 & $\begin{array}{c}689 \\
(6525)\end{array}$ & $\begin{array}{c}367 \\
(34.75)\end{array}$ \\
\hline 10. & $\begin{array}{l}\text { Upper } \\
\text { Siang }\end{array}$ & 220 & 140 & 80 & 62 & 43 & 19 & 4 & 2 & 2 & 286 & $\begin{array}{c}185 \\
(64.69)\end{array}$ & $\begin{array}{c}101 \\
(3531)\end{array}$ \\
\hline 11. & Lohit & 840 & 545 & 295 & 173 & 107 & 66 & 12 & 8 & 4 & 1025 & $\begin{array}{c}660 \\
(6439)\end{array}$ & $\begin{array}{c}365 \\
(35.61)\end{array}$ \\
\hline 12. & Changlang & 504 & 329 & 175 & 101 & 65 & 36 & 7 & 5 & 2 & 612 & $\begin{array}{c}399 \\
(6520)\end{array}$ & $\begin{array}{c}213 \\
(34.80)\end{array}$ \\
\hline 13. & $\begin{array}{l}\text { Dibang } \\
\text { Valley }\end{array}$ & 70 & 39 & 31 & 21 & 13 & 8 & 3 & 2 & 1 & 94 & $\begin{array}{c}54 \\
(57.45)\end{array}$ & $\begin{array}{c}40 \\
(4255)\end{array}$ \\
\hline 14. & $\begin{array}{c}\text { L/Dibang } \\
\text { Valley }\end{array}$ & 248 & 144 & 104 & 60 & 39 & 21 & 6 & 4 & 2 & 314 & $\begin{array}{c}187 \\
(59.55)\end{array}$ & $\begin{array}{c}127 \\
(40.45)\end{array}$ \\
\hline & Total & 6485 & 3924 & 2561 & 1639 & 1062 & 577 & 136 & 91 & 45 & 8260 & $\begin{array}{c}5077 \\
(61.46) \\
\end{array}$ & $\begin{array}{c}3183 \\
(38.54)\end{array}$ \\
\hline
\end{tabular}

\section{Arunachal Pradesh}

Source: Compiled by researcher based on- Name of Elected Panchayat Members of Arunachal Pradesh (As Notified in Extra- Ordinary Gazette of $6^{\text {th }}$ August 2003) Department of Panchayat Raj, Government of Arunachal Pradesh, Itanagar, 2003.

Notes: $\mathrm{T}=$ stand for Total, $\mathrm{M}=$ stand for Male, $\mathrm{F}=$ stand for Female, GPM = Stand for Gram Panchayat Member, ASM= stand for Anchal Samiti Member, ZPM= stand for Zilla Parishad Member.

\section{CONCLUSION}

For the first time in the history of Arunachal Pradesh, 33 per cent reservation of seats for women in the Panchayat bodies was implemented and in fact, the state have exceeded the number of women representatives in all the three levels. It is noticed that the reservation policy paved an easy entry for the women members to become panchayat leaders at different level. No male members can effort to contest on reserved seats of the women candidates. This reservation policy has increased the proportion of women's participation in panchayat now a day. It can be understand that the tribal women are getting more and more conscious about the importance of Panchayat, and treated Panchayati Raj Institution as a mark of turning point in their life. It can be assume that the presences of women in panchayat are making significant gain in the political sphere and believed that participation is rapidly empowering them and boosts their confidence and also improving their status and position in society. Women's empowerment here refers to the process by which women acquire due recognition on par with men, to participate in the development process of the society through the political institutions as a partner with human dignity. It is observed that the same tribal women, who were heisted to say single words in 'kebang' (traditional village council) now become an active path bearer for the development of the village as a whole by involving into Panchayati raj of the state.

Table-2 
Result of 2008 Panchayat Election and District-Wise Elected Members of Panchayati Raj Institution of Arunachal Pradesh

\begin{tabular}{|c|c|c|c|c|c|c|c|c|c|c|c|c|c|}
\hline \multirow{3}{*}{$\begin{array}{l}\text { S1. } \\
\text { No. }\end{array}$} & \multirow{3}{*}{$\begin{array}{l}\text { Name of } \\
\text { District }\end{array}$} & \multicolumn{9}{|c|}{ Elected No of Male/ Female } & \multirow{2}{*}{\multicolumn{3}{|c|}{ GRAND TOTAL }} \\
\hline & & \multicolumn{3}{|c|}{ GPM } & \multicolumn{3}{|c|}{ ASM } & \multicolumn{3}{|c|}{$\overline{Z M M}$} & & & \\
\hline & & $\mathrm{T}$ & $\overline{\mathrm{M}}$ & $\bar{F}$ & $\mathrm{~T}$ & $\mathrm{M}$ & $\bar{F}$ & $\mathrm{~T}$ & $\overline{\mathrm{M}}$ & $F$ & $\overline{\mathrm{T}}$ & $\begin{array}{c}\mathrm{M} \\
(\%)\end{array}$ & $\begin{array}{l}F \\
(\%)\end{array}$ \\
\hline 1. & Towing & 298 & 146 & 152 & 80 & 53 & 27 & 6 & 4 & 2 & 384 & $\begin{array}{c}203 \\
(5286)\end{array}$ & $\begin{array}{c}181 \\
(47.14)\end{array}$ \\
\hline 2. & $\begin{array}{c}\text { West } \\
\text { Kaneng }\end{array}$ & & 268 & 215 & 97 & 59 & 38 & 9 & 5 & 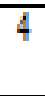 & 589 & $\begin{array}{c}332 \\
(5637)\end{array}$ & $\begin{array}{c}257 \\
(43.63)\end{array}$ \\
\hline 3. & $\begin{array}{c}\text { East } \\
\text { Kaneng }\end{array}$ & 1 & 216 & 235 & 137 & 77 & 60 & 14 & 5 & 9 & 602 & $\begin{array}{c}298 \\
(4950)\end{array}$ & $\begin{array}{c}304 \\
(5050)\end{array}$ \\
\hline 4. & Papunpare & 338 & 191 & 147 & 76 & 47 & 29 & 10 & 0 & 4 & 424 & $\begin{array}{c}244 \\
(5755)\end{array}$ & $\begin{array}{c}180 \\
(42.45)\end{array}$ \\
\hline 5 & $\begin{array}{l}\text { Rurung } \\
\text { Kundy }\end{array}$ & 555 & 293 & 262 & 155 & 103 & 52 & 13 & 9 & $\pi$ & 723 & $\begin{array}{c}405 \\
(5602)\end{array}$ & $\begin{array}{c}318 \\
(4398)\end{array}$ \\
\hline 6. & $\begin{array}{l}\text { Lower } \\
\text { Subansiri }\end{array}$ & 656 & 325 & 331 & 195 & 127 & 68 & 14 & 9 & 5 & 865 & $\begin{array}{c}461 \\
(5329)\end{array}$ & $\begin{array}{c}404 \\
(46.71)\end{array}$ \\
\hline 7. & $\begin{array}{c}\text { Upper } \\
\text { Subansiri }\end{array}$ & 516 & 284 & 232 & 148 & 99 & 49 & 14 & 9 & 5 & 78 & $\begin{array}{c}392 \\
(57.82)\end{array}$ & $\begin{array}{c}286 \\
(42.18)\end{array}$ \\
\hline 8 & $\begin{array}{l}\text { West } \\
\text { Siang }\end{array}$ & 825 & 497 & 328 & 214 & 132 & 82 & 20 & 13 & 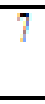 & 59 & $\begin{array}{c}642 \\
(60.62) \\
\end{array}$ & $\begin{array}{c}417 \\
(3938)\end{array}$ \\
\hline 9 & $\begin{array}{l}\text { Upper } \\
\text { Siang }\end{array}$ & 220 & 150 & 70 & 62 & 40 & 22 & 3 & 3 & 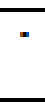 & 285 & $\begin{array}{c}193 \\
(67.72)\end{array}$ & $\begin{array}{c}92 \\
(9228) \\
\end{array}$ \\
\hline 10. & East Siang & 578 & 361 & 217 & 156 & 105 & 51 & 13 & 9 & 4 & 747 & $\begin{array}{c}475 \\
(6359)\end{array}$ & $\begin{array}{c}272 \\
(36.41)\end{array}$ \\
\hline 11. & $\begin{array}{l}\text { Dibang } \\
\text { Valley }\end{array}$ & 71 & 36 & 3 & 21 & 13 & 8 & 3 & 2 & 1 & 95 & $\begin{array}{c}51 \\
(53.68)\end{array}$ & $\begin{array}{c}44 \\
(4632) \\
\end{array}$ \\
\hline 12 & $\begin{array}{c}\text { L/Defang } \\
\text { Valley }\end{array}$ & 253 & 139 & 114 & 60 & 39 & 21 & 6 & 4 & 2 & 319 & $\begin{array}{c}182 \\
(5705)\end{array}$ & $\begin{array}{c}137 \\
(4295) \\
\end{array}$ \\
\hline 13 & Lohit & 711 & 378 & 333 & 133 & 77 & 56 & 8 & 5 & 5 & 852 & $\begin{array}{c}460 \\
(5399)\end{array}$ & $\begin{array}{c}392 \\
(4601)\end{array}$ \\
\hline 14 & Changlang & 470 & 269 & 201 & 100 & 63 & 37 & 7 & 4 & 2 & 577 & $\begin{array}{c}336 \\
(5823)\end{array}$ & $\begin{array}{c}241 \\
(41.77)\end{array}$ \\
\hline 15 & Tirap & 779 & 521 & 258 & 104 & 70 & 34 & 16 & 11 & 5 & 899 & $\begin{array}{c}602 \\
(6696)\end{array}$ & $\begin{array}{c}297 \\
(9304) \\
\end{array}$ \\
\hline 16. & Anja & 144 & 93 & 51 & 41 & 26 & 15 & 4 & 3 & 1 & 189 & $\frac{122}{(6455)}$ & $\begin{array}{c}67 \\
(35.45) \\
\end{array}$ \\
\hline & otal & 7348 & 4167 & 3181 & 1779 & 1130 & 649 & 160 & 101 & 59 & 9287 & $\begin{array}{c}5398 \\
(58.12)\end{array}$ & $\begin{array}{c}3889 \\
(41.88)\end{array}$ \\
\hline
\end{tabular}

Source: Compiled by researcher based on- Name of Elected Panchayat Members of Arunachal Pradesh (As Notified in Extra- Ordinary Gazette of 2008) Department of Panchayat Raj, Government of Arunachal Pradesh, Itanagar, 2008.

Table-3 
Result of 2013 Panchayat Election and District-Wise Elected Members of Panchayati Raj Institution of Arunachal Pradesh

\begin{tabular}{|c|c|c|c|c|c|c|c|c|c|c|c|c|c|}
\hline \multirow{3}{*}{$\begin{array}{c}\text { Si } \\
\text { No }\end{array}$} & \multirow{3}{*}{$\begin{array}{l}\text { Name of } \\
\text { Distriet }\end{array}$} & \multicolumn{9}{|c|}{ Elected No of Maje / Female } & \multirow{2}{*}{\multicolumn{3}{|c|}{ GRANDTOTAL }} \\
\hline & & \multicolumn{3}{|c|}{ GPM } & \multicolumn{3}{|c|}{ ASM } & \multicolumn{3}{|c|}{ ZPM } & & & \\
\hline & & $T$ & $M$ & F & $T$ & $\mathbf{M}$ & $\bar{F}$ & $T$ & $\mathbb{M}$ & $\bar{F}$ & $T$ & $\begin{array}{c}M \\
(\%)\end{array}$ & $\begin{array}{c}F \\
(\%)\end{array}$ \\
\hline 1 & Tamang & 301 & 165 & 142 & 30 & 31 & 29 & 05 & 4 & 2 & 395 & $\begin{array}{c}220 \\
(5595)\end{array}$ & $\begin{array}{c}177 \\
(44.02)\end{array}$ \\
\hline 2 & $\begin{array}{c}\text { Weat } \\
\text { Kameng }\end{array}$ & 454 & 226 & 258 & 97 & 32 & 45 & 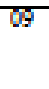 & 4 & 3 & 390 & $\begin{array}{c}232 \\
(47.90)\end{array}$ & $\begin{array}{c}305 \\
(3220)\end{array}$ \\
\hline 3. & $\begin{array}{c}\text { East } \\
\text { Kameng }\end{array}$ & 447 & 201 & 245 & 159 & 79 & 60 & 14 & 3 & 6 & 600 & $\begin{array}{c}253 \\
(48.00)\end{array}$ & $\begin{array}{c}312 \\
(3200)\end{array}$ \\
\hline 4 & Paprempare & 353 & 183 & 155 & 76 & 50 & 26 & $\mathrm{~T} 2$ & 7 & 3 & 426 & $\begin{array}{c}240 \\
(5634)\end{array}$ & $\begin{array}{c}135 \\
(43.65)\end{array}$ \\
\hline 3. & $\begin{array}{l}\text { Kervas } \\
\text { Kremey }\end{array}$ & 345 & 234 & 262 & 151 & 102 & 49 & 14 & 3 & 6 & 711 & $\begin{array}{c}394 \\
(55.41)\end{array}$ & $\begin{array}{c}317 \\
(44.59)\end{array}$ \\
\hline 6. & $\begin{array}{l}\text { Lomer } \\
\text { Sobansiri }\end{array}$ & 640 & 291 & 349 & 195 & 150 & 65 & 14 & 10 & 4 & 349 & $\begin{array}{c}431 \\
(50.77)\end{array}$ & $\begin{array}{c}413 \\
(49.23)\end{array}$ \\
\hline 7. & $\begin{array}{l}\text { Upper } \\
\text { Sabansiri }\end{array}$ & 315 & 263 & 252 & 145 & 94 & 34 & 14 & 9 & 5 & 67 & $\begin{array}{c}365 \\
(54.05)\end{array}$ & $\begin{array}{c}311 \\
(4594)\end{array}$ \\
\hline 3. & $\begin{array}{l}\text { Weat } \\
\text { Siang }\end{array}$ & 770 & 430 & 340 & 200 & 127 & 73 & 21 & 12 & 9 & 991 & $\begin{array}{c}569 \\
(57.42)\end{array}$ & $\begin{array}{c}422 \\
(42.58)\end{array}$ \\
\hline 9. & East Sang & 639 & 377 & 262 & 161 & 105 & 36 & 16 & 11 & 3 & $\$ 16$ & $\begin{array}{c}493 \\
(60.42)\end{array}$ & $\begin{array}{c}325 \\
(39.58)\end{array}$ \\
\hline 10 & $\begin{array}{l}\text { Upper } \\
\text { Siang }\end{array}$ & 205 & I3I & 73 & 39 & 36 & 23 & 7 & 3 & 2 & 272 & $\begin{array}{c}172 \\
(63.24)\end{array}$ & $\begin{array}{c}100 \\
(36.76)\end{array}$ \\
\hline III & $\begin{array}{l}\text { Dhang } \\
\text { Valley }\end{array}$ & 62 & 31 & 31 & 21 & 14 & 7 & 3 & 2 & $\mathrm{I}$ & 86 & $\begin{array}{c}47 \\
(54.65)\end{array}$ & $\begin{array}{c}39 \\
(45.35)\end{array}$ \\
\hline $\mathrm{I2}$ & $\begin{array}{c}\text { LDhang } \\
\text { Valley }\end{array}$ & 250 & 135 & 112 & 60 & 35 & 2 & 6 & 4 & 2 & 316 & $\begin{array}{c}150 \\
(5696)\end{array}$ & $\begin{array}{c}136 \\
(43.04)\end{array}$ \\
\hline I3. & Lobit & 715 & 353 & 352 & 134 & 73 & 56 & 3 & 3 & 3 & 35? & $\begin{array}{c}465 \\
(54.35)\end{array}$ & $\begin{array}{c}391 \\
(45.62)\end{array}$ \\
\hline 14. & Anga: & 144 & 90 & 34 & 41 & 26 & 15 & 4 & 3 & $\mathrm{I}$ & 139 & $\begin{array}{c}119 \\
(6295)\end{array}$ & $\begin{array}{c}70 \\
(37.04)\end{array}$ \\
\hline IS. & Changhang & 449 & 264 & 135 & 100 & 65 & 35 & II & 6 & 3 & 360 & $\begin{array}{c}335 \\
(59.52)\end{array}$ & $\begin{array}{c}225 \\
(40.18)\end{array}$ \\
\hline 16. & Trap & 332 & 226 & 106 & 56 & 35 & 18 & 7 & 3 & 2 & 395 & $\begin{array}{c}269 \\
(68.10)\end{array}$ & $\begin{array}{c}126 \\
(3190)\end{array}$ \\
\hline I7. & Longding & 445 & 250 & 195 & 45 & 35 & 13 & 9 & 6 & 3 & 503 & $\begin{array}{c}291 \\
(57.35)\end{array}$ & $\begin{array}{c}212 \\
(42.15)\end{array}$ \\
\hline & Total & 7290 & 3953 & $355 ?$ & 1766 & 1120 & 645 & 175 & 109 & 66 & 9231 & $\begin{array}{c}5162 \\
(5592)\end{array}$ & $\begin{array}{c}4069 \\
(44.05)\end{array}$ \\
\hline
\end{tabular}

Source: Compiled by researcher based on- Name of Elected Panchayat Members of Arunachal Pradesh (As Notified in Extra- Ordinary Gazette of 2013) Department of Panchayat Raj, Government of Arunachal Pradesh, Itanagar, 2013.

\section{REFERENCES:}

[1]. Dubey, S., Dynamic of Tribal Local Polity and Panchayat Raj in Arunachal Pradesh, Premier Publishing House, New Delhi, 2001

[2]. Name of Elected Panchayat Members of Arunachal Pradesh (As Notified in Extra- Ordinary Gazette of $6^{\text {th }}$ August 2003), Department of Panchayat Raj, Government of Arunachal Pradesh, Itanagar, 2003.

[3]. Name of Elected Panchayat Members of Arunachal Pradesh (As Notified in Extra- Ordinary Gazette of 2008), Department of Panchayat Raj, Government of Arunachal Pradesh, Itanagar, 2008.

[4]. Name of Elected Panchayat Members of Arunachal Pradesh (As Notified in Extra- Ordinary Gazette of 2013), Department of Panchayat Raj, Government of Arunachal Pradesh, Itanagar, 2013.

[5]. Naresh, G., Work Participation of Tribal Women in India: A Development Perspective Journal of Humanities and Social Science (IOSR-JHSS) Volume 19, Issue 12, Ver. II, Dec. 2014

[6]. Rani, G. S., N. Rajani and P. Neeraja, An Analysis of Tribal Women's Education in India, International Conference on Social Science and Humanity, IPEDR vol.5 Singapore, 2011

[7]. Statistical Profile of Scheduled Tribes" Ministry of Tribal affairs Statistical division Government of India, 2013

[8]. Yadav, A.K., Empowerment of women Through Panchayati Raj Institution: A study on East Siang District of Arunachal Pradesh, unpublished Ph. D. thesis submitted to Rajiv Gandhi University, Itanagar, 2016 